Copyright (C) 2021 University of Bucharest Printed in Romania. All rights reserved

ISSN print: $1224-5984$

ISSN online: $2248-3942$
Rom Biotechnol Lett. 2021; 26(6): 3054-3061 doi: $10.25083 / \mathrm{rbl} / 26.6 / 3054-3061$

Received for publication, August, 6, 2021

Accepted, November, 8, 2021

Original paper

\title{
Response of morphological and biochemical traits and transcriptomic of CDPKs and P5CS Genes to phytohormones and nutrients in two bread wheat germplasms under salinity conditions
}

\author{
ELHADI HADIA ${ }^{1,2}$, AMOR SLAMA ${ }^{2}$, AZIZA ZOGHLAMI ${ }^{1}$, LEILA \\ ROMDHANE ${ }^{1}$, AHMED HOUSSEIN ABODOMA ${ }^{3}$, MOHAMED ALI SAED \\ FAHEJ $^{4}$, LEILA RADHOUANE ${ }^{1}$ \\ ${ }^{1}$ University of Carthage, National Institute of Agronomic Research of Tunisia, Ariana, Tunisia. \\ ${ }^{2}$ University of Carthage, Faculty of Science, 7021 Jarzouna-Bizerte, Tunisia. \\ ${ }^{3}$ University of In Shams, Faculty of Agriculture, Department of genetics, Egypt. \\ ${ }^{4}$ University of Elmergib, College of Science, Biology Department, Khoms, Lybia
}

\begin{abstract}
Several enzymes play an important role in the biosynthesis of osmolyte in plants. The main objective of this work is to study the effects of salt stress, kinetin+potassium and giberellic acid+potassium on calcium-dependent protein kinases (CDPKs) and delta-1-pyrroline-5carboxylate synthase (P5CS) genes expression of two bread wheat varieties. The results shodwe that, salts stress reduced the plant growth of the two wheat germplasms. Moreover, the addition of kinetin + potassium improved the performance of morphometric parameters while the addition of giberellic acid + potassium has less effect. On the biochemical level, results indicated that salt stress increased the proline contents compared with control plants. Extra increase in proline contents was recorded by kinetin+ potassium, while the treatment of giberellic acid + potassium showed almost similar results as in salt stress only. On the molecular level, salt stress, kinetin and giberellic acid significantly increased the two genes expression of CDPKs and P5CS with more effect in presence of kinetin+ potassium.
\end{abstract}

Keywords Libyan bread wheat; salt stress; proline; Calcium-Dependent Protein Kinases; Delta-1pyrroline-5-carboxylate synthase; Plant growth regulator

To cite this article: HADIA EH, SLAMA A, ZOGHLAMI A, ROMDHANE L, ABODOMA AH, FAHEJ MAS, RADHOUANE L. Response of morphological and biochemical traits and transcriptomic of CDPKs and P5CS Genes to phytohormones and nutrients in two bread wheat germplasms under salinity conditions. Rom Biotechnol Lett. 2021; 26(6): 3054-3061. DOI: $10.25083 / \mathrm{rbl} / 26.6 / 3054-3061$. 


\section{Introduction}

Cereals have a great importance in agricultural research programs worldwide (SLAMA \& al 2005 [1]) and they are an essential food source for human and animals in many regions of the world. Among cereal species, bread wheat provides $20 \%$ of the calories consumed by humans and is valued for its high yield, nutritional value, and processing qualities (GUO \& al, [2]). In the Mediterranean zone, bread wheat is often exposed to salinity, which is one of the most important abiotic constraints affecting plant growth, development and grain yield. This situation will become more critical against the background of a changing climate, which already impacts agricultural production around the globe (ROMDHANE \& al [3]). As a country of the Mediterranean zone, Libya is also exposed to salt stress in addition to the low production due to many factors such the quality of seeds, the agronomic practice, and unavailability of varieties adapted to salt stress. This constraint undergoes plant growth impairment particularly at the highest salt level compared with control (BORRELLI \& al [4]). Salt stress generated significant reduction in plant height, root length and dry weight of shoots and roots (ZHENG \& al [5]). The key mechanisms of salinity tolerance in wheat were the changes in morphophysiological traits and mineral and metabolite contents after exposure to $\mathrm{NaCl}$ (BORRELLI \& al [4]). The salt tolerance of wheat could be related to its capability of restricting the transport of $\mathrm{Na}+$ at low and moderate levels to the shoots, where it is highly toxic (ZSOLDOS \& al [6]). Osmotic adjustment by accumulation of osmolytes such as proline, betaine, and soluble sugars could be used as an index of abiotic constraints tolerance in wheat. Under water deficit, compared to control plants, the foliar proline in five durum wheat cultivars showed an increase in all stressed plants with higher amplitude (6-fold) (SLAMA \& al [7]). Other researchers (ZHAO \& al [8]) found that, proline contents of leaf and root were reported at seedling stage in the three wheat (Triticum aestivum L.) varieties. Salt stress reduced the total dry matter, grain yield, chlorophyll content and relative water content, but increased proline accumulation in the maize plants.

P5CS plays a key role in proline biosynthesis, leading to osmoregulation in plants (KAYA \& al [9]). Investigated on the accumulation of proline, gene expression and activity of enzymes involved in proline metabolism, (KUBALA \& al [10] )reported that the accumulation of proline was associated with strong up-regulation of the P5CSA gene, and the up-regulated transcript level of this enzyme was consistent with the increase in P5CS activity.

Calcium ions $\mathrm{Ca} 2+$ play essential roles in plant growth and development.Calcium-dependent protein kinases (CDPKs), identified commonly in plants, are a kind of vital regulatory protein deciphering calcium signals triggered by various developmental and environmental stimuli (SHI \& al [11]). Consequently, CDPKs plays an important role in plant growth regulation and abiotic stress responses (DUBROVINA \& al [12]; SHI \& al, [11]).
WANG \& al [13] reported that individual CDPK genes responded to multiple treatments. This result provided an important foundation for the functional and evolutionary analysis of this important gene family in plants.

The enhancement of plant photosynthesis capacity and the reduction of oxidative activity under salt stress conditions could be obtained by exogenous application of potassium treatment (WEI \& al [14]). Among many tools used in classical biotechnology, various types of plant growth regulators (PGRs) are most commonly used (ZIELIŃSKA \& al [15]). These phytohormones are being widely used to counteract the deleterious effects of adverse environmental stresses on plants (KAYA \& al [9]). In addition, plant growth regulators either natural or synthetic, are extensively applied by spraying or through seed to induce abiotic stress tolerance (KADER \& al [16]). Application of PGRs improved plant resistance to abiotic stresses by manipulating different biochemical and physiological mechanisms (ANJUM \& al [17]). In fact, ABDEL-HAMID \& MOHAMED [18]) showed that themorphological characters revealed inhibition in all plant growth parameters by salinity stress and this inhibition was significantly alleviated after treatment with $\mathrm{GA}_{3}$. Foliar applications of kinetin treatment overcame to variable extents the adverse effects of $\mathrm{NaCl}$ stress on the morpho-metric and physiological parameters, reduced $\mathrm{Na}+$ concentration and increased those of $\mathrm{Ca} 2+$ and $\mathrm{K}+$ (KAYA \& al [9]).

In this respect, our investigation aimed to study the effects of salt stress on the growth of two bread wheat cultivars and to study the effects of spray application of $\mathrm{Ki}, \mathrm{GA} 3$ and potassium on proline contents and the genes expression of CDPKs and P5CS compared to plants grown under control condition.

\section{Materials and Methods}

This study was conducted in agriculture research centre in Libya at Keaam station. Two bread wheat varieties (Triticum aestivum L.) were used: Krassie and Bohoot 210.

\section{Plant material}

Krassie is an old Libyan variety cultivated in the south of Libya near the coast in the region Wadi-Ataba. The Culture of this variety was decreased in early 1970s due the using of new improved varieties selected by the research institute to improve durum wheat productivity.

Bohoot 210 is a selected variety created in 2014 by the agriculture research center (ARC) in, Libya in collaboration with the international center for improvement of maize and wheat (CIMMYT).

\section{Experimental conditions}

This study was conducted in agriculture research centre, Keaam station, Libya and molecular biology lab, department of genetics, Fac. Agriculture, Ain Shams Univ., Egypt. Two spray treatments: Kinetin + potassium and GA3 + potassium were used in order to improve the two varieties plant for salt tolerance. Culture was undertaken in hydroponic system trial with three replications extended for 10 days after germination. 
Plants of the two wheat cultivars were grown in hydroponic system in factorial experiment with three replications and four treatments under full controlled conditions. The treatments were the following:

- $\quad$ control (C)

- $\quad$ Salinity (S): $5000 \mathrm{ppm} \mathrm{NaCl,}$

- $\quad 5000 \mathrm{ppm} \mathrm{NaCl}+(80 \mathrm{ppm} \mathrm{ki}+1500 \mathrm{mg} / \mathrm{L}$ potassium nitrate) spray $5000 \mathrm{ppm} \mathrm{NaCl}+(50 \mathrm{ppm} \mathrm{GA} 3+1500 \mathrm{mg} / \mathrm{L}$ potassium nitrate) spray.

The morphological measured traits were shoot fresh weight (SFW), number of roots $\left(n^{\circ} \mathrm{R}\right)$, shoot length (SL) and root length (RL). One quarter of Hoagland solution was add as source of nutrients for the plants in the hydroponic system.

\section{Proline extraction and determination}

Proline was extracted as described by (BATES \& al [19]) by grinding $0.5 \mathrm{~g}$ of fresh leaf tissues of each treatment in three replications then $10 \mathrm{ml}$ of $3 \%$ sulfosalicylic acid solution was added at $4{ }^{\circ} \mathrm{C}$. The extract was filtered using Wattman $n^{\circ} 1$ filter paper, the filtered solution was collected in a tube. Two $\mathrm{mL}$ of glacial acetic acid and $2 \mathrm{~mL}$ of nenhydrin solution were added to $2 \mathrm{~mL}$ of each sample extract and boiled in a water bath for an hour. Four ml of toluene was add to the previous mixture and shacked strongly for 20 seconds. Proline concentration was measured using $1 \mathrm{~mL}$ of the previous mixture immediately after the addition of toluene, using spectrophotometer at wavelength $520 \mathrm{~nm}$. Standards of proline solutions ranged from 0.04 to $1 \mathrm{mM}$, in the same medium as the one used for extraction.

\section{Molecular studies}

The effects of four treatments on CDPKs and P5CS gene expression were examined using QPCR in the molecular biology lab, department of genetics, Fac. Agriculture, Ain Shams Univ., Egypt. Leaves samples of the two wheat cultivars of all treatments were collected to extract the RNA.

\section{$R N A$ extraction and real time $R T-P C R$}

Total RNA extraction was performed on the fresh wheat tissue by the Gene JET Plant RNA Purification Mini Kit (Thermo Scientific, EU). The cDNA was synthesized from the extracted RNA using Revert-Aid First Strand cDNA Synthesis Kit (Thermo Scientific).

Quantitative Reverse transcription-PCR (RT-PCR) for (CDPKs) and (P5CS) genes were conducted. RNA of both varieties of all treatments in three replications was reverse transcribed (RT), to produce the first strand of cDNA in the presence of $5 \mathrm{mM} \mathrm{MgCl}$, 1 X PCR Buffer, 1 mMdNTPs, $25 \mathrm{u}$ MuLV Reverse Transcriptase, and $4 \mathrm{u}$ RNA-guard Ribonuclease inhibitor. The mixture was prepared in three different PCR tubes. $2.5 \mu \mathrm{l}$ of $20 \mathrm{P}$ mol of CDPKs reveres primer with the following sequence (AAT TGA TGG CCA TGG CCT GAC TTT C) was added to the mixture in one of the three PCR tubes. In the second tube $2.5 \mu \mathrm{l}$ of $20 \mathrm{P}$ mol of P5CS reveres primer with the following sequence (GTA AAG CGT ATC CGC ACT AAC GC) was added in a final reaction volume of $30 \mu \mathrm{l}$ in each tube. Reactions were carried out at $42{ }^{\circ} \mathrm{C}$ for $30 \mathrm{~min}$, followed by a $10 \mathrm{~min}$ step at $94{ }^{\circ} \mathrm{C}$ to denature the enzyme, then was cooling at $4{ }^{\circ} \mathrm{C}$.
To assay Real time PCR quantification of cDNA encoding for CDPKs and P5CS, one $\mu 1$ of cDNA of each samples was used as template in the reaction mix, in a final volume of $25 \mu \mathrm{l}$ in all assays. Real time PCR, using CDPKs and P5CS forward and reverse primers with the following sequences [CDPKs forward (TGA GTA AGG CCG ACA AGG AGG ATA), reverse (AAT TGA TGG CCA TGG CCT GAC TTT C)] and [P5CS forward (ATT CCG ACC TTG TGT AAC CGG C), reverse (GTA AAG CGT ATC CGC ACT AAC GC)], respectively, were employed to define the detection limit of the assay.

Cycling was carried out in a Stratagene Mx-3000 Realtime PCR system which allows the detection of most commercially available dyes including FAM, SYBR ${ }^{\circledR}$

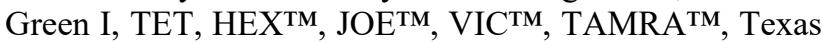
Red $\AA, \operatorname{ROX}^{\mathrm{TM}}, \mathrm{Cy}^{\mathrm{TM}}$, Cy3 ${ }^{\mathrm{TM}}$ and ALEXA Fluor ${ }^{\circledR} 350$. The system supports 96 -well plate format and can perform multiple sub experiments up to four dyes in the same well. Bioron product, SYBR ${ }^{\circledR}$ Green I Real Time QPCR (cat No. 119205) master mix for (100 rcs) detection protocol was used in this investigation as described in Bioron manual.

\section{Quantification of CDPKs, PEPCs and P5CS genes} expression

Sq RT-PCR quality and concentration was measure by use of a Quawell Q5000 UV-Vis spectrophotometer (V2.1.4, USA).

\section{Statistical analyses}

Statistical analysis (ANOVA) was performed using SAS software.To compare means the least significant difference (LSD) test was used. The difference was considered significant at $\mathrm{P}<0.05$.

\section{Results and discussion}

\section{Effect of treatments on morphological traits}

Four traits were used to assess the effects of the three treatments as compared to the control plants: shoot fresh weight (SFW), number of roots $\left(n^{\circ} \mathrm{R}\right)$, shoot length (SL) and root length (RL). The results were recorded in tables $(1,2)$.

$$
\% \text { variation }=100-\left(\frac{\text { treatment }}{\text { control }} \times 100\right) .
$$

In general, salt stress leads to the highest reduction ratio as proportion of control of the two wheat cultivars under investigation (Tables 1, 2). The response for salt stress was varied between the two wheat cultivars.

On the other hand, the results in table (1) and table (2) indicated that, kinetin with potassium and GA3 with potassium acted as improvements for plant salt tolerance. In shoot fresh weight, the reduction was greater under only salt stress compared to the treatment of salt stressed plants sprayed by kinetin with potassium and GA3 with potassium. Similar results were obtained from shoot length and root length, while in number of roots, the results revealed that, in cultivar Bohoot 210 kinetin and GA3 improved this trait over the control. The, shoot dry weight of Krassie also increased over control when plants were treated with phytohormones. 
Table 1. Effect of the treatments on the morphological traits of the two wheat varieties

\begin{tabular}{|c|l|l|l|l|c|}
\hline Variety & Treatment & RL & SL & \multicolumn{1}{|c|}{$\mathbf{n}^{\mathbf{R}}$} & SFW \\
\hline \multirow{4}{*}{ Krassie } & control & $5.167 \pm 0.13$ & $5.80 \pm 0.18$ & $4.867 \pm 0.18$ & $41.367 \pm 0.61$ \\
\cline { 2 - 6 } & $\mathrm{S}$ & $2.567 \pm 0.05$ & $3.167 \pm 0.05$ & $4.033 \pm 0.06$ & $25.567 \pm 0.27$ \\
\cline { 2 - 6 } & $\mathrm{Ki}+\mathrm{K}+\mathrm{S}$ & $3.721 \pm 0.07$ & $4.152 \pm 0.06$ & $4.464 \pm 0.11$ & $43.230 \pm 0.32$ \\
\cline { 2 - 6 } & $\mathrm{GA} 3+\mathrm{K}+\mathrm{S}$ & $3.970 \pm 0.07$ & $4.475 \pm 0.27$ & $4.458 \pm 0.10$ & $42.638 \pm 0.20$ \\
\hline \multirow{5}{*}{ Bohoot 210} & $\mathrm{Control}$ & $3.40 \pm 0.05$ & $3.633 \pm 0.10$ & $4.033 \pm 0.07$ & $24.767 \pm 0.58$ \\
\cline { 2 - 6 } & $\mathrm{S}$ & $1.767 \pm 0.13$ & $2.133 \pm 0.03$ & $3.667 \pm 0.06$ & $16.833 \pm 0.24$ \\
\cline { 2 - 6 } & $\mathrm{Ki}+\mathrm{K}+\mathrm{S}$ & $2.367 \pm 0.03$ & $3.133 \pm 0.03$ & $4.20 \pm 0.08$ & $23.767 \pm 0.11$ \\
\cline { 2 - 6 } & $\mathrm{GA} 3+\mathrm{K}+\mathrm{S}$ & $2.633 \pm 0.32$ & $3.233 \pm 0.08$ & $4.767 \pm 0.03$ & $22.807 \pm 0.03$ \\
\hline
\end{tabular}

RL: root length, SL: shoot length, $n^{\circ} \mathrm{R}$ : number of roots, SFW: shoot dry weight, $\mathrm{S}$ : salinity treatment, $\mathrm{Ki}+\mathrm{K}+\mathrm{S}$ : kinetin + potassium nitrate + salinity, GA3+K+S: giberellic acid + potassium nitrate + salinity, S: salinity, Ki: kinetin, K: potassium nitrate, GA3: giberellic acid, $( \pm)$ standard deviation

Table 2. Variation of the morphological traits in \% compared to control treatment of the two wheat varieties

\begin{tabular}{|c|l|c|c|c|c|}
\hline Variety & Treatment & RL & SL & $\mathbf{n}^{\mathbf{0}} \mathbf{R}$ & SFW \\
\hline \multirow{3}{*}{ Krassie } & $\mathrm{S} / \mathrm{C}$ & -50.3 & -45.4 & -17.13 & -38.19 \\
\cline { 2 - 6 } & $\mathrm{Ki}+\mathrm{K}+\mathrm{S} / \mathrm{C}$ & -27.98 & -28.4 & -8.28 & +4.504 \\
\cline { 2 - 6 } & $\mathrm{GA} 3+\mathrm{K}+\mathrm{S} / \mathrm{C}$ & -23.16 & -22.85 & -8.40 & +3.072 \\
\hline \multirow{3}{*}{ Bohoot 210} & $\mathrm{~S} / \mathrm{C}$ & -48.3 & -41.29 & -9.07 & -32.035 \\
\cline { 2 - 7 } & $\mathrm{Ki}+\mathrm{K}+\mathrm{S} / \mathrm{C}$ & -30.38 & -13.76 & +4.21 & -4.038 \\
\cline { 2 - 7 } & $\mathrm{GA} 3+\mathrm{K}+\mathrm{S} / \mathrm{C}$ & -22.55 & -12.01 & +18.20 & -7.914 \\
\hline
\end{tabular}

RL: root length, SL: shoot length, $n^{\circ} \mathrm{R}$ : number of roots, $\mathrm{SFW}$ : shoot dry weight, $\mathrm{S}$ : salinity treatment, $\mathrm{Ki}+\mathrm{K}+\mathrm{S}$ : kinetin + potassium nitrate + salinity, GA3 $+\mathrm{K}+\mathrm{S}$ : giberellic acid + potassium nitrate + salinity, S: salinity, Ki: kinetin, K: potassium nitrate, GA3: giberellic acid, (-): decrease, $(+)$ : increase

Analysis of variance of morphological traits of the two bread wheat varieties (Table 3) showed significant differences for all studied parameters. Duncan's Multiple Range (Table 4) of root length (RL), shoot length (SL), number of roots (noR) and shoot dry weight (SFW) classified the two studied varieties into two groups: Krassie a and Bohoot ${ }^{b}$. The local variety had the high values for all parameters.

Duncan's Multiple Range (Table 4) showed also that for root length (RL) and roots number $\left(n^{\circ} R\right)$, all treatment were different and were classified in four groups. For shoot length (SL) application of GA3 classified this treatment in the first position (4.615a) followed by $\mathrm{Ki}$ and the control treatment in the same group (position b). For shoot dry weight (SFW), application of Ki classified this treatment in the first place followed by the control treatment and GA3.

Table 5 showed significant correlations between all morphological parameters with two high correlations. Root length (RL) was correlated to the number of roots (noR) (0.98023) and the shoot dry weight (SFW) was correlated to root length (RL) (0.85680).

Table 3. Analysis of variance of morphological parameters of the two bread wheat varieties

\begin{tabular}{|c|c|c|c|c|c|c|}
\hline Source & Effect & df & SS & MS & $\mathbf{F}$ & P-value \\
\hline \multirow{3}{*}{ RL } & Variety & 1 & 10.52 & 10.52 & 556.89 & $<0.0001 * * *$ \\
\hline & Treatment & 3 & 13.86 & 4.62 & 244.57 & $<0.0001 * * *$ \\
\hline & Variety ${ }^{\mathrm{x}}$ Treatment & 3 & 0.656 & 0.218 & 11.57 & $0.0003 * *$ \\
\hline \multirow{3}{*}{ SL } & Variety & 1 & 0.663 & 0.663 & 72.10 & $<0.0001^{* * *}$ \\
\hline & Treatment & 3 & 2.004 & 0.668 & 72.62 & $<0.0001^{* * *}$ \\
\hline & Variety ${ }^{\mathrm{x}}$ Treatment & 3 & 1.024 & 0.341 & 37.10 & $<0.0001 * * *$ \\
\hline \multirow{3}{*}{$\mathbf{n}^{0} \mathbf{R}$} & Variety & 1 & 10.948 & 10.948 & 681.97 & $<0.0001^{* * *}$ \\
\hline & Treatment & 3 & 13.007 & 4.33 & 270.08 & $<0.0001^{* * *}$ \\
\hline & Variety ${ }^{\mathrm{x}}$ Treatment & 3 & 1.362 & 0.454 & 28.30 & $<0.0001 * * *$ \\
\hline \multirow{3}{*}{ SFW } & Variety & 1 & 1570.75 & 1570.75 & 12648.2 & $<0.0001^{* * *}$ \\
\hline & Treatment & 3 & 643.703 & 214.567 & 1727.77 & $<0.0001^{* * *}$ \\
\hline & Variety ${ }^{\mathrm{x}}$ Treatment & 3 & 117.419 & 39.139 & 315.17 & $<0.0001^{* * *}$ \\
\hline
\end{tabular}

RL: root length, SL: shoot length, $\mathrm{n}^{ } \mathrm{R}$ : number of roots, $\mathrm{SFW}$ : shoot dry weight, $\mathrm{S}$ : salinity treatment, $\mathrm{Ki}+\mathrm{K}+\mathrm{S}$ : kinetin + potassium nitrate + salinity, GA3+K+S: giberellic acid + potassium nitrate + salinity, S: salinity, Ki: kinetin, K: potassium nitrate, GA3: giberellic acid, $\mathrm{df}=$ degree of freedom; $\mathrm{SS}=$ sum of squares; $\mathrm{MS}=$ mean square; $\mathrm{F}=$ Fisher test; $\mathrm{p}=$ probability: ${ }^{* * *}$ significant at 0.0001, **significant at 0.001; Variety: Krassie and Bohoot 210; Treatment: control, salinity, $\mathrm{Ki}+\mathrm{K}+\mathrm{S}, \mathrm{GA} 3+\mathrm{K}+\mathrm{S}$ 
Table 4. Duncan's Multiple Range of root length (RL), shoot length (SL), number of roots ( $\left.{ }^{\circ} \mathrm{R}\right)$ and shoot dry weight $(\mathrm{SFW})$ (two-way ANOVA, variety $\times$ treatment) for the two varieties, Krassie and Bohoot 210 under the different treatments

\begin{tabular}{|c|l|l|l|l|l|}
\hline \multirow{4}{*}{ Variety } & & RL & SL & n & SFW \\
\cline { 2 - 6 } & Krassie & $3.857 \mathrm{a}$ & $4.50 \mathrm{a}$ & $4.397 \mathrm{a}$ & $38.203 \mathrm{a}$ \\
\cline { 2 - 6 } & Bohoot 210 & $2.533 \mathrm{~b}$ & $4.167 \mathrm{~b}$ & $3.046 \mathrm{~b}$ & $22.023 \mathrm{~b}$ \\
\hline \multirow{4}{*}{ Treatment } & Control & $4.285 \mathrm{a}$ & $4.450 \mathrm{~b}$ & $4.7150 \mathrm{a}$ & $33.07 \mathrm{ab}$ \\
\cline { 2 - 6 } & Salinity & $2.151 \mathrm{~d}$ & $3.850 \mathrm{c}$ & $2.650 \mathrm{~d}$ & $21.155 \mathrm{c}$ \\
\cline { 2 - 6 } & Ki+K $+\mathrm{S}$ & $3.045 \mathrm{c}$ & $4.420 \mathrm{~b}$ & $3.640 \mathrm{c}$ & $33.50 \mathrm{a}$ \\
\cline { 2 - 6 } & GA3+K+S & $3.30 \mathrm{~b}$ & $4.615 \mathrm{a}$ & $3.883 \mathrm{~b}$ & $32.725 \mathrm{~b}$ \\
\hline
\end{tabular}

Duncan groupement: different letters ( $a, b, c, d)$ indicate significant differences according to Duncan's Multiple Range Test. S: salinity treatment, $\mathrm{Ki}+\mathrm{K}+\mathrm{S}$ : kinetin + potassium nitrate + salinity, $\mathrm{GA} 3+\mathrm{K}+\mathrm{S}$ : giberellic acid + potassium nitrate + salinity, $\mathrm{S}$ : salinity, Ki: kinetin, K: potassium nitrate, GA3: giberellic acid

Table 5. Correlations between root length (RL), shoot length (SL), number of roots (noR) and shoot dry weight (SFW)

\begin{tabular}{|l|l|l|l|l|}
\hline & RL & SL & $\mathbf{n}^{\mathbf{0}}$ & SFW \\
\hline RL & 1 & 0.0002 & $<0.0001$ & $<0.0001$ \\
\hline SL & 0.69719 & 1 & $<0.0001$ & 0.0003 \\
\hline $\mathbf{n}^{\mathbf{0}} \mathbf{S F W}$ & 0.98023 & 0.75677 & 1 & $<0.0001$ \\
\hline
\end{tabular}

At the left: correlation coefficients of Pearson. At the right: probability $($ Prob $>|r|)$

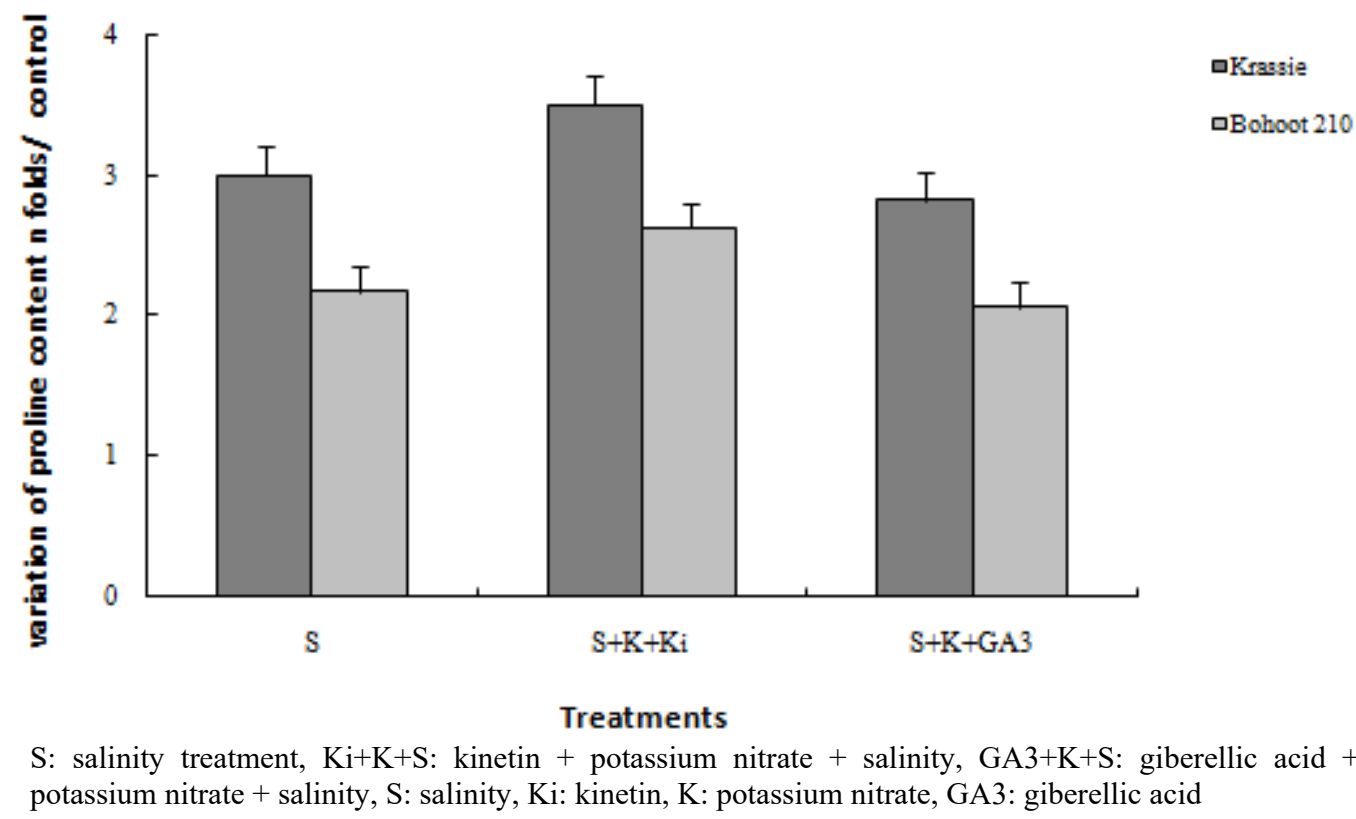

Figure 1. Changes in proline contents by the three treatments compared to controls of the two varieties

\section{Effect of treatments on proline content}

In biochemical level, proline was measured in control and tkinetip + potassium and salt stressed + GA3 + potassium aforementioned treatments in the two wheat cultivars under invespegctioely in cultivar Krassie; while in cultivar Changes in proline (Pr) contents were calculated according to tBepopt210 proline contents increased by 2.17, 2.63, and formula:

Variation of Pr content $\mathrm{n}$ fold /control $=\frac{\text { treatment }}{\text { control }}$

The results of proline contents as shown in figure 1 indicated that proline contents increased compared to
2.06 in salt stressed, salt stressed + kinetin + potassium and salt stressed + GA3 + potassium, respectively. The treatment of Krassie and Bohooth210 with GA3 did not improve the proline contents compared to the salinity treatment. The increase of proline content was most elevated when plants were treated by kinetin compared to 
salinity treatment for the both varieties. A significant increase of proline in Krassie under all treatments was found compared to Bohooth210.

\section{Gene expression of CDPKs and P5CS as response for}

\section{the three treatments}

Gene expression changes of $C D P K S$ and P5CS under salinity and spray treatments with $\mathrm{Ki}+$ potassium and $\mathrm{GA} 3+$ potassium were recorded in figure 2.

\section{Gene expression profiles of CDPKs}

The expression patterns analysis in response to salt stress and the two other treatments revealed significant induction in the expression level of CDPKs. Salt stress induced in Krassie cultivar, compared to control, an increase of 2.46 times of gene expression whereas, spraying stressed plants with $\mathrm{Ki}+$ potassium and GA3 + potassium increased this trait up to 5.77 times and 4.14 times compared to control plants respectively. In Bohoot210, the results of the gene expression of CDPKs indicated that under salt stress condition the gene expression increased up to 1.6 folds compared to control while, in the salt stressed plants which sprayed with ki + potassium the gene expression induced up to 2.89 times. Finally, the gene expression in the stressed plants sprayed with GA3 + potassium induced up to 2.38 times compared to control. It was revealed that Kinetin caused more significant changes in the expression level of CDPKs of the plants of both varieties more than GA3. In addition, Krassie showed more changes than Bohoot 210 in all cases.

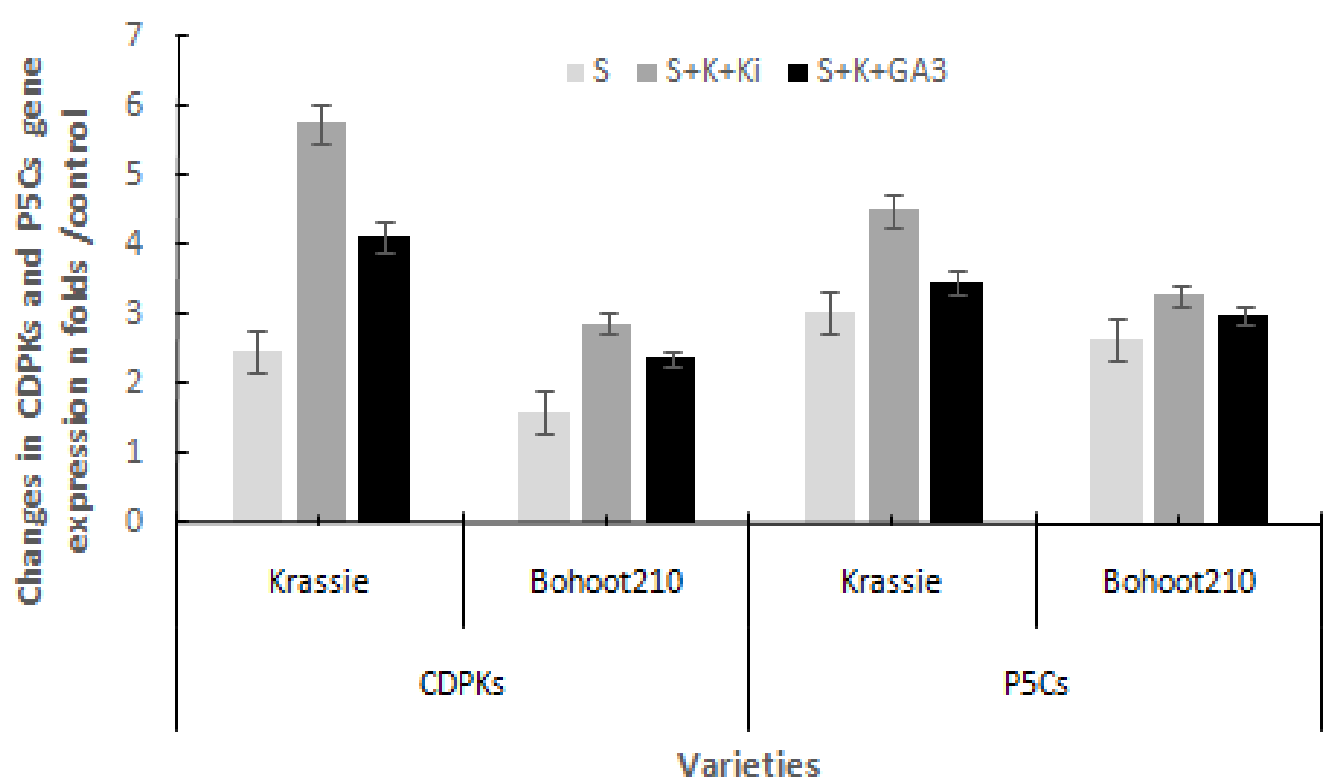

$\mathrm{S}$ : salinity treatment, $\mathrm{Ki}+\mathrm{K}+\mathrm{S}$ : kinetin + potassium nitrate + salinity, $\mathrm{GA} 3+\mathrm{K}+\mathrm{S}$ : giberellic acid + potassium nitrate + salinity, S: salinity, Ki: kinetin, K: potassium nitrate, GA3: giberellic acid.

Figure 2. Effects of the three treatments on gene expression of CDPKs and P5CS compared to control plants of the two wheat varieties

\section{Gene expression of P5CS}

The expression patterns analysis in response to salt stress and phytohormones treatments also revealed significant induction in the expression level of P5CS. Salt stress increased the gene expression of P5CS in Krassie cultivar by 3.03 times, $\mathrm{Ki}+$ potassium and GA3 + potassium 4.5 times and 3.46 times of this trait respectively. In cultivar Bohoot210, the results of the gene expression of P5CS indicated an increase of the gene expression up to 2.639 folds, 3.294 and 3.00 folds compared to control in the salt stressed plants, plants sprayed with $\mathrm{ki}+$ potassium and treatment with GA3 + potassium, respectively. Applying Kinetin to plants submitted to salt stress improved the gene expression of P5CS more than GA3 for booth varieties. Salinity and phytohormones induced an increase of this trait in Krassie more than Bohoot 210.
Plant tolerance to abiotic constraints can be improved by a number of means including selection and breeding, genetic modifications, and use of osmoprotectants and growth regulating substances (PARIDA \& DAS [20]). The present study aimed to evaluate and assess whether Kinetine and GA3 can alleviate the negative effects of salt stress on two Libyan varieties through monitoring the mor-physiological and molecular traits.

It was revealed that salt stress caused significant reduction of the morphological parameters of both varieties. The present study classified the studied cultivars into two groups with respect to morphological traits, the selected variety Bohoot appeared to be more reactive, with a low reduction under salt stress, whereas local variety Krassie was characterized by a particular strategy of prevention, their values were still much higher than those 
of Bohoot despite the high decrease even at salt stress conditions. This variety seems to be more adapted to its local environment than the selected one. To enhance the tolerance of plants to abiotic stress different methods were performed including the use of phytohormones. Salt stress induced decline in morphological and agronomic attributes were counteracted by the application of PGRs (IQBAL \& ASHRAF [21]). In our study, we have demonstrated the effectiveness of these plant growth regulators in reducing the effect of salt stress.The reduction recorded in the presence of Kinetin and GA3 became less pronounced and we observed even an increase of some parameters compared to the controls treatment (without salt). The response variations appeared to be similar to those of KAYA \& al [9] where the foliar applications of kinetin overcame to variable extents the adverse effects of $\mathrm{NaCl}$ stress on the physiological parameters.

It was found that the change in proline content is able to distinguish between treatments and the two varieties. Proline content raise ranged from 2.82 to 3.5 folds in Krassie and between 2.06 to 2.63 folds in Bohoot compared to control. On the basis of this osmoregulator, the local variety was found more resistant to the salt stress as compared to the recent variety Bohoot. Proline content was significantly increased by the application of Kinetin than the GA3 for both varieties. Consequently, Kinetin treatment may be recommended as a potential method of improving salt stress tolerance by enhancing proline synthesis in bread wheat.

In addition, we evaluated in the present study the effects of salt stress and the plant growth regulators on the variation of gene expression of P5CS that plays a key role in proline biosynthesis, leading to osmoregulation in plants (KAYA \& al [9]). The accumulation of proline is an important mechanism for osmotic regulation in plants suggested to salt stress. Under this constraint (HUANG \& al [22]) reported an accumulate of proline in stems and leaves as well as P5CS enzyme activities were increased, moreover, transcript levels of P5CS increased in response to $\mathrm{NaCl}$ stress. Our findings were in agreement with those of MANSOUR \& ALI [23] who reported that plant salt tolerance is a complex trait and studies based solely on proline accumulation do not necessarily explain its function in salinity tolerance.

In this paper we studied also the effects of salt stress and the plant growth regulators on the variation of gene expression of CDPKs that plays an important role in plant growth regulation and abiotic stress responses (DUBROVINA \& al [12]). Previous studies illustrated that CDPKs are important sensors of $\mathrm{Ca}^{++}$flux in plants and plays essential roles in plant development and adaptation to various abiotic stresses. Our study showed an increase ranged between 1.6 to 5.77 folds of CDPKs. $\mathrm{HO} \&$ al [22] indicated that the expression levels of some protein kinase, and phosphatase genes along with other transcription factors were up-regulated (up to two to 70 fold) in leaves of tolerant genotype plants under salt stress conditions. DUBROVINA \& al [12] recorded a significant induction of the expression level of 13 CDPK genes using RT-PCR under abiotic stress in leaves of wild-growing grapevine. These results are agreed with our finding.

CDPKs and P5Cs play different roles in osmotic adjustment. P5CS plays a key role in proline biosynthesis while CDPKs (Calcium-dependent protein kinases), is protein that decipher calcium signals generated by some environmental constraints including salt stress, CDPK genes, actively expressed in the abiotic stress conditions (DUBROVINA \& al [12]). Significant differences between varieties were found when CDPKs and P5Cs genes expressions were compared. For Bohoot210, the gene expression of P5Cs was more activated by the seed priming than CDPKs whereas for Krassie CDPKs was more elevated. Krassie had the highest values of gene expression of the two enzymes and the Kinetin seems to be more efficient in the change of gene expression of the two enzymes. Our result are in agreement with those of (IQBAL \& ASHRAF [21]) which showed that moderate concentration of Kinetin had a consistent effect in altering the growth under salt stress conditions.

\section{Conclusion}

The higher values of morphological traits of Krassie under salt stress confirmed the major role of proline in the osmotic adjustment and the high activity of gene expression of CDPKs and P5Cs observed in this study. This local variety seems to be more tolerant to the local conditions characterized by high salinity water.

Kinetin application affected positively the morpophysiological traits of both varieties more than GA3. Therefore, the tolerance of bread wheat to salt stress could be improved by the supply of Kinetin.

\section{Acknowledgments}

This work was supported by the Plant Physiology Laboratory of National Institute of Agronomic Research of Tunisia, the Agriculture Research Centre in Libya and the Agriculture Faculty, Ain shams University, Egypt.

\section{References}

1. SLAMA A., SALEM M.B., NACEUR M.B., ZID E. Les céréales en Tunisie: production, effet de la sécheresse et mécanismes de résistance. Sci. Chang. Planétaires Sécher. 2005; 16: 225-229.

2. GUO G., LIU X., SUN F., CAO J., HUO N., WUDA B., XIN M., HU Z., DU J., XIA R., ROSSI V., PENG H., NI Z., SUN., YAO Y.: WHEAT MIR9678 Affects Seed Germination by Generating Phased siRNAs and Modulating Abscisic Acid/Gibberellin Signaling. Plant Cell. 2018; 3: 796-814.

https://doi.org/10.1105/tpc. 17.00842

3. ROMDHANE L., FERRO N.D., SLAMA A., RADHOUANE L. Optimizing irrigation and determining the most sensitive development stage to 
drought in barley (Hordeum vulgare L.) in a semiarid environment. Acta Bot. Croat. 2020; 79.

4. BORRELLI G.M., FRAGASSO M., NIGRO F., PLATANI C., PAPA R., BELEGGIA R., TRONO D. Analysis of metabolic and mineral changes in response to salt stress in durum wheat (Triticum turgidum ssp. durum) genotypes, which differ in salinity tolerance. Plant Physiol. Biochem. PPB. 2018; 133: 57-70. https://doi.org/10.1016/j.plaphy.2018.10.025

5. ZHENG Y., JIA A., NING T., XU J., LI Z., JIANG G. Potassium nitrate application alleviates sodium chloride stress in winter wheat cultivars differing in salt tolerance. J. Plant Physiol. 2008; 165: 14551465. https://doi.org/10.1016/j.jplph.2008.01.001

6. ZSOLDOS F., HAUNOLD E., VASHEGYI A., HERGER P. Effects of sodium chloride stress and calcium supply on growth, potassium uptake, and internal chloride and sodium levels of winter wheat seedlings. Acta Biol. Hung. 1990; 41: 399-408.

7. SLAMA A., MALLEK-MAALEJ E., BEN MOHAMED H., RHIM T., RADHOUANE L. A return to the genetic heritage of durum wheat to cope with drought heightened by climate change. PLOS ONE. 2018; 13.

https://doi.org/10.1371/journal.pone.0196873

8. ZHAO Y., MA Y.Q., WENG Y.J. Variation of betaine and proline contents in wheat seedlings under salt stress. Journal of Plant Physiology and Molecular Biology 2005; 31: 103-106.

9. KAYA C., TUNA A.L., OKANT A.M. Effect of foliar applied kinetin and indole acetic acid on maize plants grown under saline conditions; Turk J Agric. 2010; 34: 529-538.

10. KUBALA S., WOJTYLA Ł., QUINET M., LECHOWSKA K. LUTTS S., GARNCZARSKA, M. Enhanced expression of the proline synthesis gene P5CSA in relation to seed osmopriming improvement of Brassica napus germination under salinity stress. J. Plant Physiol. 2015; 183: 1-12. https://doi.org/10.1016/j.jplph.2015.04.009

11. SHI S., LI S., ASIM M., MAO J., XU, D., ULLAH Z., LIU, G., WANG, Q., LIU, H.:The Arabidopsis Calcium-Dependent Protein Kinases (CDPKs) and Their Roles in Plant Growth Regulation and Abiotic Stress Responses. Int. J. Mol. Sci. 2018; 19. https://doi.org/10.3390/ijms19071900

12. DUBROVINA A.S., KISELEV K.V., KHRISTENKOV. S. Expression ofcalcium-dependent protein kinase (CDPK) genes under abiotic stress conditions in wild-growing grapevine Vitis amurensis. J. Plant Physiol. 2013; 170: 1491-1500.

https://doi.org/10.1016/j.jplph.2013.06.014

13. WANG Q., YIN X., CHEN Q., XIANG N., SUN X., YANG Y., YANG Y. Genome-wide survey indicates diverse physiological roles of the turnip (Brassica rapa var. rapa) calcium-dependent protein kinase genes. Sci. Rep. 2017; 7.

https://doi.org/10.1038/s41598-017-16102-0

14. WEI D.D., CHENG D., LIU W.B., LIU T., YANG X.H., ZHENG Y.H. Adequate potassium application enhances salt tolerance of moderate-halophyte Sophora alopecuroides. Plant Soil Environ. 2015; 61: 364-370. https://doi.org/10.17221/232/2015-PSE

15. ZIELIŃSKA S., PIĄTCZAK E., KOZŁOWSKA W., BOHATER A., JEZIERSKA-DOMARADZKA A., KOLNIAK-OSTEK J., MATKOWSKI A. LED illumination and plant growth regulators' effects on growth and phenolic acids accumulation in Moluccella laevis L. in vitro cultures. Acta Physiol. Plant. 2020; 42: 72. https://doi.org/10.1007/s11738020-03060-W

16. KADER M.A., LINDBERG S., SEIDEL T., GOLLDACK D., YEMELYANOV V. Sodium sensing induces different changes in free cytosolic calcium concentration and $\mathrm{pH}$ in salt-tolerant and sensitive rice (Oryza sativa) cultivars. Physiol. Plant. 2007; 130: 99-111. https://doi.org/10.1111/j.13993054.2007.00890.x

17. ANJUM S.A., WANG L.C., FAROOQ M., HUSSAIN M., XUE L.L., ZOU C.M. Brassinolide Application Improves the Drought Tolerance in Maize Through Modulation of Enzymatic Antioxidants and Leaf Gas Exchange. J. Agron. Crop Sci. 2011; 197: 177-185. https://doi.org/10.1111/j.1439-037X.2010.00459.x

18. ABDEL-HAMID A.M.E., MOHAMED H.I. The effect of the exogenous gibberellic acid on two salt stressed barley cultivars. Eur. Sci. J. ESJ. 2014; 10.

19. BATES L.S., WALDREN R.P., TEARE I.D.:Rapid determination of free proline for water-stress studies. Plant Soil. 1973; 39: 205-207. https://doi.org/10.1007/BF00018060

20. PARIDA A.K., DAS A.B.: Salt tolerance and salinity effects on plants: a review. Ecotoxicol. Environ. Saf. 2005; 60: 324-349. https://doi.org/10.1016/j.ecoenv.2004.06.010

21. IQBAL M., ASHRAF M. Presowing Seed Treatment with Cytokinins and Its Effect on Growth, Photosynthetic Rate, Ionic Levels and Yield of Two Wheat Cultivars Differing in Salt Tolerance. $J$. Integr. Plant Biol. 2005; 47: 1315-1325. https://doi.org/10.1111/j.1744-7909.2005.00163.x

22. HUANG Z., ZHAO L., CHEN D., LIANG M., LIU Z., SHAO H., LONG X. Salt stress encourages proline accumulation by regulating proline biosynthesis and degradation in Jerusalem artichoke plantlets. PloS One. 2013; 8: e62085. https://doi.org/10.1371/journal.pone.0062085

23. MANSOUR M.M.F., ALI E.F. Evaluation of proline functions in saline conditions. Phytochemistry. 2017; 140: 52-68. https://doi.org/10.1016/j.phytochem.2017.04.016

24. HO S L., HUANG L F., LU C.A., HE S L., WANG C C., YU S P., CHEN J., YU S.M. Sugar starvationand GA-inducible calcium-dependent protein kinase 1 feedback regulates GA biosynthesis and activates a 14-3-3 protein to confer drought tolerance in rice seedlings. Plant Mol. Biol. 2013; 81: 347-361. https://doi.org/10.1007/s11103-012-0006-z 